\title{
Strategy for Improving the Implementation of Performance Accountability System for Government Institution (SAKIP): A Case Study in the Directorate General of Human Settlements (Ditjen Cipta Karya), the Ministry of Public Works and Housing, Indonesia
}

\author{
Farida Kusuma Wardhani ${ }^{1}$, Ubud Salim², ${ }^{2}$ Sudjatno $^{2}$ \\ ${ }^{1}$ Master of Management of Faculty of Economics and Business, Brawijaya University \\ ${ }^{2}$ Faculty of Economics and Business, Brawijaya University \\ Corresponding Author: Farida Kusuma Wardhani
}

\section{ABSTRACT}

The Government Performance Accountability System (SAKIP) is a systematic series of activities as well as tools and procedures designed to determine, measure, collect data, classify, summarize, and report the accountability and the improvement of government agency performance to the government. The level of performance accountability of the Directorate General of Human Settlements (Cipta Karya), the Ministry of Public Works and Housing from 2015-2019 experienced fluctuation indicating that the organizational performance management is considered not optimal. Therefore, this study elucidates the implementation of performance management (SAKIP), analyzes the root cause, and formulates a strategy to improve the implementation of SAKIP at the Directorate General of Human Settlements (Cipta Karya), the Ministry of Public Works and Housing. This qualitative research employed a case study. The result of this study revealed that the implementation of SAKIP has not run optimally with eight repeated problems as seen from the evaluation conducted by the Inspectorate General. The root causes of SAKIP implementation are the programs based on presidential directive (budgeted), no regulations/Standard Operating Procedure (SOP) related to SAKIP, no performance cascading, non-integrated information systems, leadership awareness, and evaluator capacity. The strategy for improving the implementation of SAKIP includes solving performance measurement, drafting rules/SOP related to SAKIP, constructing the performance tree, integrating information systems, and SAKIP training for leaders and evaluators. The performance management issues for each organization are different. Thus, future researchers are expected to conduct further research related to performance management in various central and local government organizations.

Keywords: Performance Management, Accountability, Government, SAKIP, Strategy

\section{INTRODUCTION}

Currently, there is a paradigm shift of the government organization management from the Old Public Administration with top-down hierarchy and limited citizen involvement, to the New Public Management (NPM) with the focus on performance/results and high-quality public services for the community. NPM emphasizes the need for changes in public sector management by adopting the business sector management to resolve the poor management systems in the public sector (Bovaird and Loffer, 2013). They can be 
Farida Kusuma Wardhani et.al. Strategy for improving the implementation of performance accountability system for government institution (SAKIP): a case study in the directorate general of human settlements (ditjen cipta karya), the ministry of public works and housing, Indonesia.

implemented in the form of strategic management and performance management, which is the part of strategic management in the implementation stage (Poister and Streib, 1999). This research delineates in more detail the performance management in government organizations.

In Indonesia, there regulation governing the performance management in government agencies is the Presidential Regulation Number 29 of 2014 on Government Agencies Performance Accountability System (SAKIP). The SAKIP is a systematic series of activities as well as tools and procedures designed to determine, measure, collect data, classify, summarize, and report the accountability and the improvement of government agency performance to the government. The implementation of SAKIP includes six aspect, namely performance planning, performance agreements, performance measurement, performance data management, performance reporting, and performance evaluation and review. An accountable government organization runs the six aspects of SAKIP optimally.

One of the government agencies to move towards a result-oriented performance is the Ministry of Public Works and Housing (Kementerian PUPR) since it has issued Ministerial Regulation Number 09 of 2018 concerning the Implementation of SAKIP at the Ministry of Public Works and Housing. One of the agencies that is obliged to implement it is the Echelon I Organizational Units, the Directorate General of Human Settlement. It is in charge of the formulation and implementation of policies in the residential development, building arrangement development, drinking water supply system development, and wastewater, environmental drainage, and waste management system development. Currently, the Directorate General of Human Settlements (Cipta Karya) has made efforts to implement SAKIP in its management system as shown by the formulation of a grand design for the
SAKIP implementation, a balanced score card to measure organizational performance, and the use of e-SAKIP as an organizational performance management information system. However, the implementation is considered not optimal.

According to the results of the assessment of the Inspectorate General (Itjen) of the Ministry of Public Works and Housing, the performance accountability score of the Directorate General of Human Settlement is categorized as very good with a score range of 70-80. However, the score has fluctuated in the last 5 years. There are still many notes from the Inspectorate General that are repeated every year in terms of improvement of organizational performance. Thus, it can be concluded that the organization has not been able to fix errors optimally and performance management is running by itself (autopilot) since there is no strategy to improve the performance management.

Referring to previous studies, there is limited research related to the relationship among problems in performance management or how the problems occur as the majority of studies only deal with the problems that already occur (Ahenkan et al., 2018; Chandrasekar, 2008; Davies, 1999; de Waal and Counet, 2009; Hatry, 2002; Ohemeng, 2009; Poister, 2010). In addition, there is few studies at the Echelon I Organizational Unit at the ministry establishing a novelty for this research. For this reason, this study elucidates the implementation of SAKIP, analyzes the root cause, and formulates a strategy to improve the implementation of SAKIP at the Directorate General of Human Settlements (Cipta Karya), the Ministry of Public Works and Housing to be more optimal, effective, and efficient.

\section{LITERATURE REVIEW Performance Management}

In

general,

performance management is a process to ensure that a series of activities and outputs meet organizational goals effectively and 
Farida Kusuma Wardhani et.al. Strategy for improving the implementation of performance accountability system for government institution (SAKIP): a case study in the directorate general of human settlements (ditjen cipta karya), the ministry of public works and housing, Indonesia.

efficiently. Performance management can focus on the performance of organizations, departments, employees, or existing processes to manage particular tasks (Harris et al., 2003). According to Lee (2005), the real purpose of a performance management system consists of three things, namely enhancing performance, maintaining performance, and increasing performance. This is in line with De Waal and Coevert (2007) that the use of a performance management system can improve overall organizational performance and quality.

In government organizations, performance management as a system requires a systematic process. Thus, it is necessary to formulate an appropriate design for a performance management system to achieve optimal performance. The government organization's performance management system should include the procedures, steps, and stages forming a performance cycle. Generally, as part of the performance accountability system, the performance management cycle is divided into five stages: (a) performance planning; (b) performance implementation, (c) performance measurement and evaluation; (d) performance reporting, (e) performance audits (Bappenas, 2006).

Referring to several previous studies, there are problems of the government organizations' performance management and their optimization strategies that are grouped based on factors that affect performance, namely organizational, resource, work and ICT systems, and external factors as depicted in Table 1.

Table 1. Problems of Performance Management in Government Organizations

\begin{tabular}{|c|c|c|}
\hline No. & $\begin{array}{l}\text { Problems of Performance Management in } \\
\text { Government Organizations }\end{array}$ & Sources \\
\hline \multicolumn{3}{|c|}{ Organization } \\
\hline 1 & $\begin{array}{l}\text { The goal is unclear/there is no identification of the } \\
\text { desired outcome }\end{array}$ & $\begin{array}{l}\text { Hatry (2002), GAO (2004), Chandrasekar (2008), de Waal and Counet (2009), } \\
\text { Issachar (2009) in Ahenkan et al., (2018), Firdausy and Hanifah (2018) }\end{array}$ \\
\hline 2 & $\begin{array}{l}\text { Unclear strategies/activities have impacted } \\
\text { outcomes }\end{array}$ & Hatry (2002), de Waal and Counet (2009), Firdausy and Hanifah (2018) \\
\hline 3 & $\begin{array}{l}\text { Indicators cannot be used to measure success/ } \\
\text { indicators are inaccurate }\end{array}$ & $\begin{array}{l}\text { Davies (1999), Chandrasekar (2008), de Waal and Counet (2009), Issachar } \\
\text { (2009) in Ahenkan et al., (2018), Firdausy and Hanifah (2018) }\end{array}$ \\
\hline 4 & $\begin{array}{l}\text { Organizational culture is not ready to carry out } \\
\text { performance management }\end{array}$ & de Waal and Counet (2009), Ohemeng (2009), Poister (2010) \\
\hline \multicolumn{3}{|c|}{ Resources } \\
\hline 1 & $\begin{array}{l}\text { The lack of commitment from the } \\
\text { management/leader (accountability is symbolic) }\end{array}$ & $\begin{array}{l}\text { de Waal and Counet (2009), Ohemeng (2009), Issachar (2009) in Ahenkan et } \\
\text { al., (2018) }\end{array}$ \\
\hline 2 & Lack of resource capacity & $\begin{array}{l}\text { Davies (1999), Bappenas (2006), de Waal and Counet (2009), Issachar (2009) } \\
\text { in Ahenkan et al., (2018), Poister (2010), Ahenkan et al., (2018) }\end{array}$ \\
\hline 3 & $\begin{array}{l}\text { Lack of training in performance management } \\
\text { systems for members }\end{array}$ & de Waal and Counet (2009), Issachar (2009) in Ahenkan et al., (2018) \\
\hline 4 & Financial constraints & Bappenas (2006), Ahenkan et al., (2018) \\
\hline 5 & No support from stakeholders (internal) & $\begin{array}{l}\text { Davies (1999), de Waal and Counet (2009), Issachar (2009) in Ahenkan et al., } \\
\text { (2018) }\end{array}$ \\
\hline \multicolumn{3}{|c|}{ Work and ICT Systems } \\
\hline 1 & $\begin{array}{l}\text { There is no clear policy/design for performance } \\
\text { management system }\end{array}$ & Chandrasekar (2008), Ahenkan et al., (2018) \\
\hline 2 & $\begin{array}{l}\text { There is no procedure for how to use information } \\
\text { or feedback to improve performance }\end{array}$ & Hatry (2002), Chandrasekar (2008), Ohemeng (2009) \\
\hline 3 & There is no reward and punishment & $\begin{array}{l}\text { GAO (2004), de Waal and Counet (2009), Ohemeng (2009), Ahenkan et al., } \\
\text { (2018) }\end{array}$ \\
\hline 4 & $\begin{array}{l}\text { Difficulty in obtaining data to measure indicators } \\
\text { or obtain relevant data }\end{array}$ & Hatry (2002), GAO (2004), de Waal and Counet (2009) \\
\hline 5 & Poor bureaucratic management & Bappenas (2006) \\
\hline 6 & $\begin{array}{l}\text { Poor communication/lack of coordination between } \\
\text { parties }\end{array}$ & Bappenas (2006), Ahenkan et al., (2018) \\
\hline 7 & $\begin{array}{l}\text { Inadequate Information and Communication } \\
\text { Technology (ICT) systems }\end{array}$ & de Waal and Counet (2009), Poister (2010) \\
\hline \multicolumn{3}{|c|}{ External } \\
\hline 1 & $\begin{array}{l}\text { Public indifference so there is no pressure for } \\
\text { public officials }\end{array}$ & Ohemeng (2009) \\
\hline
\end{tabular}


Farida Kusuma Wardhani et.al. Strategy for improving the implementation of performance accountability system for government institution (SAKIP): a case study in the directorate general of human settlements (ditjen cipta karya), the ministry of public works and housing, Indonesia.

Table 2 Strategies for Improving Government Organization Performance

\begin{tabular}{|c|c|c|}
\hline No. & Strategies for Improving Government Organization Performance & Sources \\
\hline \multicolumn{3}{|c|}{ Organization } \\
\hline 1 & Creating a shared vision and mission of all stakeholders & Ahenkan et al., (2018) \\
\hline 2 & $\begin{array}{l}\text { Creating an organizational culture that identifies and improves performance and } \\
\text { transparency of each process }\end{array}$ & $\begin{array}{l}\text { Davies (1999), Niven (2003), Fryer et al., } \\
\text { (2009) }\end{array}$ \\
\hline \multicolumn{3}{|c|}{ Resources } \\
\hline 1 & Increase the commitment and support of leaders & $\begin{array}{l}\text { Niven (2003), Bappenas (2006), Fryer et al., } \\
\text { (2009), Poister (2010), Ahenkan et al., (2018) }\end{array}$ \\
\hline 2 & Leaders motivate employees & Ahenkan et al., (2018) \\
\hline 3 & Providing training to employees (HR) to improve the performance & Bappenas (2006), Poister (2010) \\
\hline 4 & $\begin{array}{l}\begin{array}{l}\text { Stakeholder involvement/active participation in performance management } \\
\text { (internal) }\end{array} \\
\end{array}$ & Davies (1999), Fryer et al., (2009) \\
\hline 5 & Allocating internal budget to make the program more effective & Poister (2010) \\
\hline \multicolumn{3}{|c|}{ Work and ICT Systems } \\
\hline 1 & $\begin{array}{l}\text { Constructing rules related to performance management, in terms of agreement on } \\
\text { the interpretation of actions and the use of performance information }\end{array}$ & Davies (1999), Poister (2010) \\
\hline 2 & $\begin{array}{l}\text { Building a performance management system that connects employee and leader } \\
\text { performance data }\end{array}$ & Poister (2010), Ahenkan et al., (2018) \\
\hline 3 & Coordinating performance management systems and strategies & Fryer et al., (2009) \\
\hline 4 & Collecting and reporting performance data more frequently and on time & Hatry (2002) \\
\hline 5 & $\begin{array}{l}\text { Monitoring and reviewing performance on an ongoing basis and discuss } \\
\text { strategies to achieve objectives }\end{array}$ & $\begin{array}{l}\text { Fryer et al., (2009), Poister (2010), Ahenkan et } \\
\text { al., (2018) }\end{array}$ \\
\hline 6 & $\begin{array}{lcccc}\begin{array}{l}\text { Complementing performance information with explanations } \\
\text { performance data (good/bad results) as the lesson for organizations }\end{array} & & \text { to } \\
\end{array}$ & $\begin{array}{l}\text { Davies (1999), Hatry (2002), Fryer et al., } \\
(2009)\end{array}$ \\
\hline 7 & Establishing a follow-up for feedback, for example with regular surveys & $\begin{array}{l}\text { Boschken (1992), Hatry (2002), Fryer et al., } \\
(2009)\end{array}$ \\
\hline 8 & Establishing a performance management system with rewards and punishment & $\begin{array}{l}\text { Heinrich (2002), Bappenas (2006), Ahenkan et } \\
\text { al., (2018) }\end{array}$ \\
\hline 9 & Open communication system between leaders and employees & Ahenkan et al., (2018) \\
\hline 10 & Creating contingency plans for dealing with environmental uncertainty & Hatry (2002) \\
\hline 11 & Alignments between management and information technology & Niven (2003) \\
\hline \multicolumn{3}{|c|}{ External } \\
\hline 1 & $\begin{array}{l}\text { Creating performance partnerships at different levels of governments/sectors } \\
\text { (external) }\end{array}$ & Poister (2010), Ahenkan et al., (2018) \\
\hline
\end{tabular}

\section{Performance Accountability System for Government Agencies (SAKIP)}

The Performance Accountability System for Government Agencies (SAKIP) is a systematic series of various activities, tools, and procedures designed for determining and measuring, collecting data, classifying, summarizing, and reporting performance to government agencies for accountability and performance improvement of government agencies (Presidential Regulation Number 29 Year 2014 on SAKIP). This system is related to the concept of new public management since the criteria in this concept form the basis of SAKIP implementation.

The implementation of SAKIP aims to ensure that governance and development can take place in an efficient, effective, responsible manner and free from collusion, corruption, and nepotism (KKN). Hence, SAKIP is an instrument in realizing the concept of good governance. The SAKIP cycle includes six aspects, namely strategic plans, performance agreements, performance measurement, performance data management, performance reporting and review, and performance evaluation.

\section{METHODS}

This research is qualitative research, a process based on a methodology that investigates a social phenomenon and human problems. This study employed a case study, in which the researcher explores certain entities or phenomena identified as "cases" that are limited by time and activity (for example, programs, events, institutions, or social groups) and collects detailed information through many data collection procedures over a constant period of time (Creswell, 1998). Case studies provide descriptive explanations of the experiences of the entity and/or behavior recorded in field notes, interviews (formal and conversational), surveys, or observations (Patton, 2002). Thus, a semi-structured interview was conducted to dig information related to the implementation of SAKIP of 
Farida Kusuma Wardhani et.al. Strategy for improving the implementation of performance accountability system for government institution (SAKIP): a case study in the directorate general of human settlements (ditjen cipta karya), the ministry of public works and housing, Indonesia.

the Directorate General of Human Settlements.

Table 3. Research Informants

\begin{tabular}{|c|c|c|c|}
\hline No & Name & Role & \\
\hline 1 & $\begin{array}{ll}\text { Mr. } & \text { Bhima } \\
\text { Dhananjaya } & \\
\end{array}$ & \multirow{3}{*}{$\begin{array}{l}\text { Internal Evaluators of the SAKIP at the } \\
\text { Directorate General of Human Settlements } \\
\text { (Cipta Karya) }\end{array}$} & \multirow{3}{*}{$\begin{array}{l}\text { Implementing the SAKIP at the Directorate General of } \\
\text { Human Settlements (Cipta Karya), (preparation of } \\
\text { strategic plans, performance agreements, performance } \\
\text { measurement, performance data management, and } \\
\text { performance reporting) }\end{array}$} \\
\hline 2 & $\begin{array}{ll}\text { Mr. } & \text { Juniarto } \\
\text { Ramadhan } & \\
\end{array}$ & & \\
\hline 3 & $\begin{array}{ll}\text { Ms. } & \text { Oktalina } \\
\text { Mayasari } & \end{array}$ & & \\
\hline 4 & $\begin{array}{ll}\text { Mr. } & \text { Sasmito } \\
\text { Wihantoro } & \end{array}$ & $\begin{array}{l}\text { Evaluators of the SAKIP at the Inspectorate } \\
\text { General of the Ministry of Public Works and } \\
\text { Housing }\end{array}$ & Evaluate the implementation of SAKIP \\
\hline 5 & Ms. Melly Septiani & $\begin{array}{l}\text { Human Resources Development } \\
\text { Agency(BPSDM) of the Ministry of Public } \\
\text { Works and Housing }\end{array}$ & Guiding the implementation of SAKIP \\
\hline
\end{tabular}

Data analysis for the interview was carried out in three stages, namely data reduction, data presentation, and conclusion drawing with content analysis. According to Bungin (2001), content analysis is an integrative and more conceptual method of analysis to find, identify, process, and analyze documents in order to understand their meaning, significance, and relevance. The results of interviews were transcribed and drawn into main points related to the research objectives. The next stage was data presentation by systematically explaining relevant information such as describing the SAKIP implementation, the problems and the root causes of problems, and future improvement strategies. The final stage was the objective conclusion drawing and triangulation to examine the valid results of interviews with the informants. To describe the causal relationship of the problems, the researcher used the root-cause analysis technique and visualizes the root of the problem in the form of a root-cause tree based on the aspects of the implementation of SAKIP and based on problems that recur from year to year from the evaluation of SAKIP by the Inspectorate General annually.

\section{RESULTS}

The Implementation of SAKIP at the Directorate General of Human Settlements (Cipta Karya)

The implementation of SAKIP at the Directorate General of Human Settlements (Cipta Karya) is based on the Ministerial
Regulation Number 09 of 2018 concerning the Implementation of SAKIP at the Ministry of Public Works and Housing. The SAKIP cycle of the Directorate General of Human Settlements starts from performance planning that focuses on the strategic plan (renstra) of the Directorate General of Human Settlements (Cipta Karya) based on the strategic plan of the Ministry of Public Works and Housing. Then, the strategic plan is outlined in the budget plan in the form of RKAK/L (Ministry/Agency Work Plan and Budget) to become a DIPA (Budget Implementation List) equipped with a POK (Project Operational Manual) as the basis for a PK (Performance Agreement) between the Directorate General of Human Settlements (Cipta Karya) and the Ministry of Public Works and Housing. At the beginning of the year, an action plan is prepared to describe the steps in implementing the plan based on the Performance Agreement. Itis monitored and evaluated on a monthly basis in the form of monthly monitoring and evaluation (monev). At the end of the year, the monthly monitoring and evaluation report become one of the bases for preparing the performance report. In terms of individual accountability, planning starts from planning employee performance, then compiling SKP (Employee Performance Targets) which are monitored and assessed as the basis for giving rewards and punishments.

The fluctuation described from the evaluation of the implementation of SAKIP 
Farida Kusuma Wardhani et.al. Strategy for improving the implementation of performance accountability system for government institution (SAKIP): a case study in the directorate general of human settlements (ditjen cipta karya), the ministry of public works and housing, Indonesia.

of the Directorate General of Human based on a letter from the Inspectorate Settlements (Cipta Karya) in 2015-2019 is General. It can be seen in Figure 1.

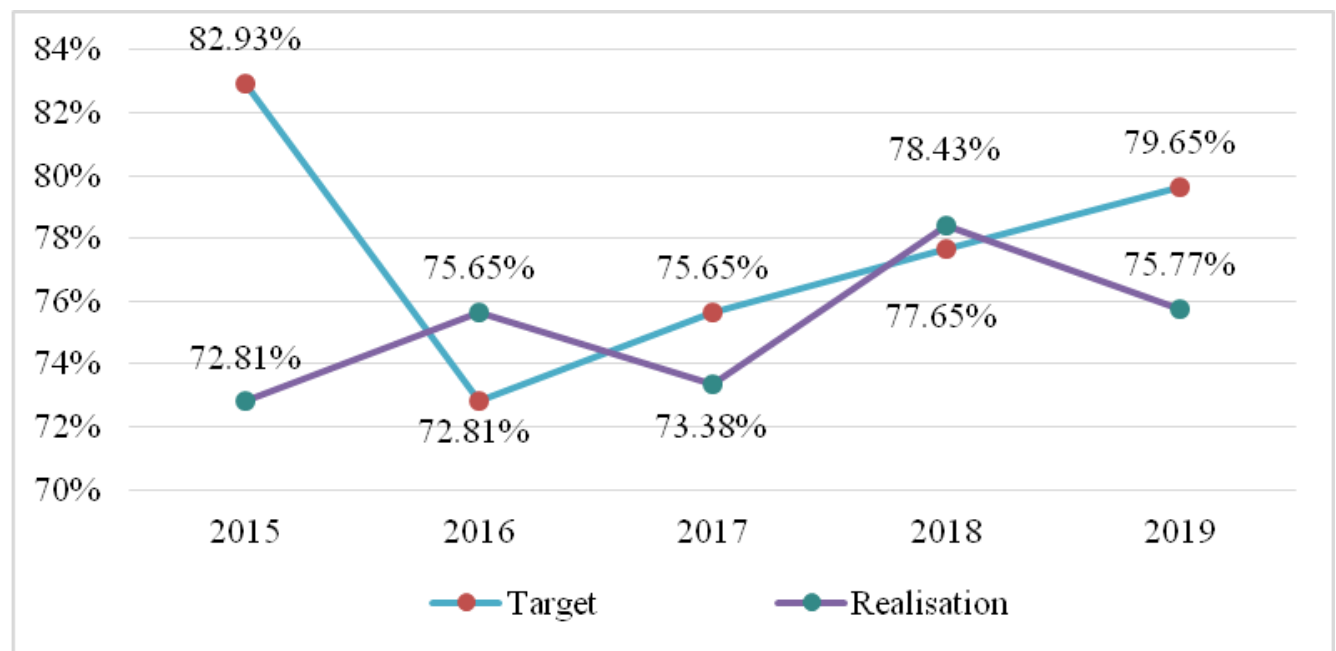

Figure 1. Target and Realisation of the Score of the SAKIP of the Directorate General of Human Settlements from 2015 to 2019

The fluctuation of the SAKIP score indicates that organizational performance is considered as not optimal. In addition, based on the results of interviews, a common issue related to the implementation of SAKIP at the Directorate General of Human
Settlements is that SAKIP is considered a formality. There is no cascading of organizational performance to individuals and there is no specific institution dealing with SAKIP at the organizational level and the Ministerial level.

\section{The Root Cause of the SAKIP Implementation at the Directorate General of Human Settlements (Cipta Karya)}

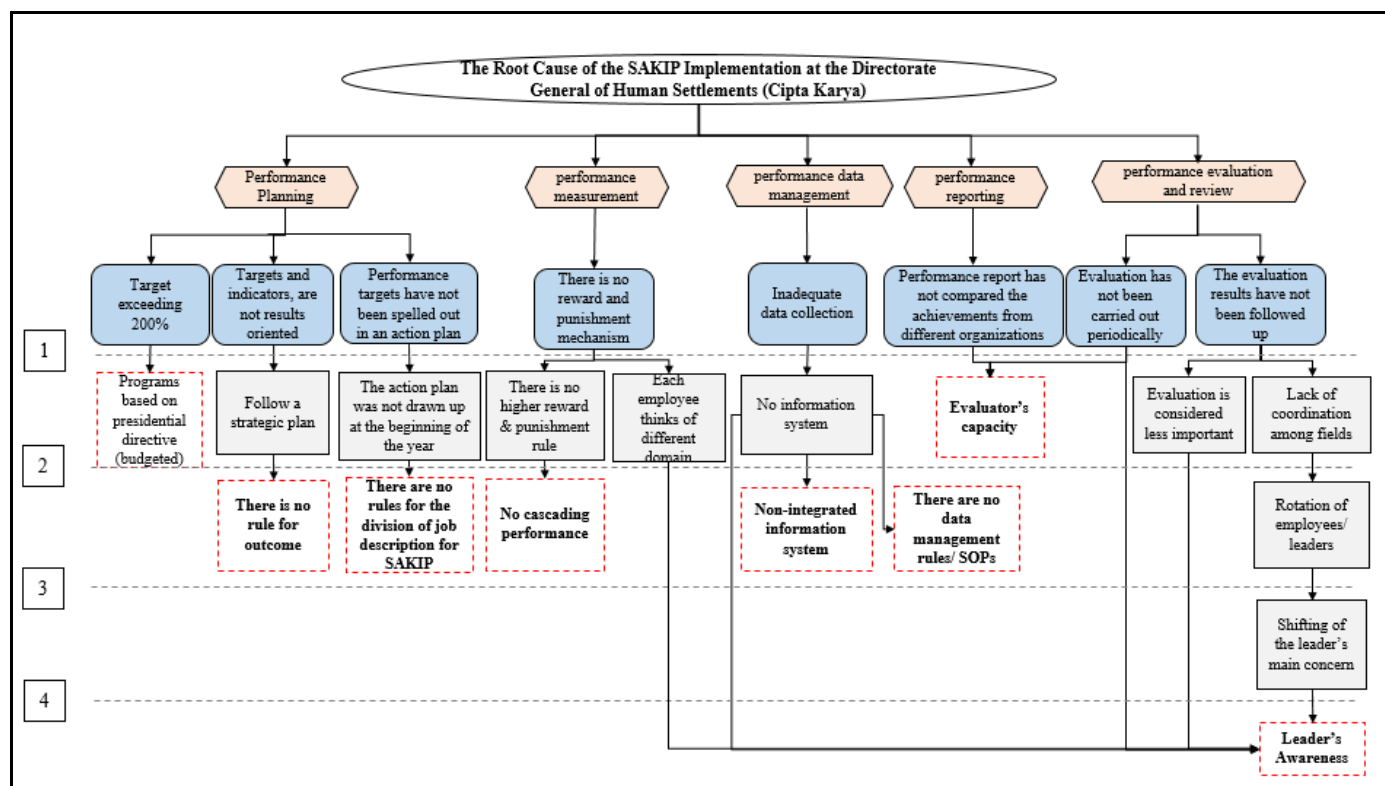

Figure 2. Root-Cause Tree of the Problems in SAKIP Implementation at the Directorate General of Human Settlements (Cipta Karya)

Based on the evaluation results conducted by the Inspectorate General, there were eight performance management problems that had been repeated until 2019. They were examined to find the root cause. 
Farida Kusuma Wardhani et.al. Strategy for improving the implementation of performance accountability system for government institution (SAKIP): a case study in the directorate general of human settlements (ditjen cipta karya), the ministry of public works and housing, Indonesia.

\section{Performance Planning}

- The performance target set in the strategic plan exceeds $200 \%$. This is because the programs based on president directive (budgeted) occur incidentally according to the circumstances so that the target increases beyond the planning. According to Bappenas (2006), the uncontrollable problem of bureaucratic management is common in government organizations.

- The objectives and indicators set in the work unit planning are not the cause of the outcome as in 2019, there is no regulation of the result-oriented. Echelon I (the Director-General of Cipta Karya) has a result-oriented target (outcome) but cannot be implemented at echelon II (director) and the subs. Hatry (2002) describes the problem of organizational performance management such as not identifying the desired results as well as strategies to achieve them. The absence of a clear and enforceable performance management policy is one of the problems in performance management (Issachar, 2009 in Ahenkan et al., 2018).

- The performance targets in the annual performance planning have not been fully elaborated into periodic targets in the action plans. This is because the action plans were not prepared at the beginning of the year asall aspects of SAKIP were handled by the Monitoring and Evaluation Sub-Directorate, even though the action plans were the domain of the Planning Sub-Directorate. The root cause is the lack of job description in the implementation of SAKIP at the Directorate General of Human Settlements. In the future, a ratified regulation is required. This is in accordance with Poister (2010) in his research that performance management requires regulations in each institution in order to enhance performance.

\section{Performance Measurement}

The results of performance measurement (achievement) at the echelon IV level and above have not been used as a basis for providing incentives, promotion, as well as reward and punishment because there is no reward and punishment rule. Furthermore, this occurs because there is no performance cascading (the process of defining strategic objectives, key performance indicators (KPI), and organizational goals vertically and horizontally (from higher levels to lower levels in order to create harmony in the organization) as a basis for setting rules (root cause 1). This also occurs in the United States. Based on the GAO (2004) report, the US government experienced difficulties in linking the performance measurement of institutions, programs, units, and individuals and the reward system. In addition, the absence of reward and punishment occurs because of the accountability of organizations and individuals in a different field and each thinks of a different domain, even though SAKIP is mutual organizational accountability composed by individual accountability. The root cause is low leadership awareness regarding performance management. Ahenkan et al., (2018) explain that low commitment from high officials is a problem of performance management.

\section{Performance Data Management}

The data collected is not based structured mechanism as it does not use an information system (manual). The information systems are not integrated. This happens because of the low level of awareness among leaders on performance management. On the other hand, there is another root cause such as no rules/SOP for data management. Thus, the data collection will be accidental and not systemized. This is in line with the research results reported by de Waal and Counet (2009) that the current ICT system in government organizations is not sufficient to support a performance management system. 
Farida Kusuma Wardhani et.al. Strategy for improving the implementation of performance accountability system for government institution (SAKIP): a case study in the directorate general of human settlements (ditjen cipta karya), the ministry of public works and housing, Indonesia.

\section{Performance Reporting}

The performance report has compared the organizational achievements and the similar organizations due to the new evaluator capacity. It is due to changes in the organizational structure at the Inspectorate General of the Ministry of Public Works and Housing. Previously, the Directorate General of Human Settlements (Cipta Karya) was evaluated by Inspectorate V. Now, it is evaluated by Inspectorate III that has never evaluated SAKIP before. This problem was not raised during the evaluation but instead became a note when the evaluation results were submitted to the organization. In line with that, Ahenkan et al., (2018) described one of the problems of performance management in government organizations as the inadequate capacity of human resources to set clear goals and objectives, as well as assessment and evaluation standards for performance measurement.

\section{Performance Evaluation and Review}

- The evaluation of the performance accountability has been supervised. However, there is no documentation of communication or regular discussions due to the low awareness of the leaders. There is miscommunication that evaluations have been carried out periodically. In this context, the evaluation referred to is the evaluation of the internal SAKIP, but the new
Inspectorate General asked about program evaluation. It can be concluded that the capacity of the evaluator is one of the root causes of this problem. Problems related to inadequate capacity of evaluators are one of the inhibitors in performance management (Bappenas, 2006).

- The results of internal evaluation have not been followed up on improvements to planning or the implementation of performance management due to lack of coordination among fields. It is due to the rotation of employees/leaders making the leadership's concern is changing. In addition, evaluation can never be used because the results of the evaluation are not considered as something important by the leaders. Hatry (2002) confirms that the focus of the government is only on measurement, with little attention to how to use the information to help the program improve. This happens due to the low awareness exhibited by the leaders (de Waal and Counet, 2009).

\section{Strategies to Improve the Implementation of SAKIP in the Directorate General of Human Settlements (Cipta Karya)}

Based on the results of the rootcause analysis outlined in the root-cause tree, there are eight root causes that need to be addressed with various strategies in order to improve organizational performance.

Table 2. Strategies to Improve the Implementation of SAKIP in the Directorate General of Human Settlements (Cipta Karya)

\begin{tabular}{|c|c|c|c|c|}
\hline No. & \multicolumn{2}{|l|}{ Root Causes } & \multicolumn{2}{|l|}{ Strategies } \\
\hline 1 & \multicolumn{2}{|c|}{ Programs based on presidential directive (budgeted) } & \multicolumn{2}{|l|}{ Solving performance measurement } \\
\hline 2 & \multicolumn{2}{|r|}{ No $\quad$ regulations/ $\quad$ Standard } & Formulation of outcome rules & \multirow{3}{*}{$\begin{array}{l}\text { Drafting rules/Standarc } \\
\text { Operating Procedure (SOP) } \\
\text { related to SAKIP }\end{array}$} \\
\hline 3 & $\begin{array}{l}\text { No regulation of job } \\
\text { description for SAKIP }\end{array}$ & $\begin{array}{l}\text { Operating Procedure (SOP) } \\
\text { related to SAKIP }\end{array}$ & $\begin{array}{l}\text { The drafting of a Circular of the } \\
\text { Director-General of Human } \\
\text { Settlements on SAKIP }\end{array}$ & \\
\hline 4 & $\begin{array}{l}\text { No regulations/SOP for } \\
\text { data management }\end{array}$ & & $\begin{array}{l}\text { Drafting of SOP for data } \\
\text { management }\end{array}$ & \\
\hline 5 & \multicolumn{2}{|l|}{ No performance cascading } & \multicolumn{2}{|c|}{ Constructing performance tree (performance cascading) } \\
\hline 6 & \multicolumn{2}{|c|}{ Non-integrated information systems } & \multicolumn{2}{|l|}{ Integration of information systems } \\
\hline 7 & \multicolumn{2}{|l|}{ Leader's awareness } & \multicolumn{2}{|l|}{ SAKIP training for leaders } \\
\hline 8 & \multicolumn{2}{|l|}{ Evaluator capacity } & \multicolumn{2}{|l|}{ SAKIP training for evaluators } \\
\hline
\end{tabular}

1. To solve performance measurement in addressing the root cause of the programs based on presidential directive (budgeted) requires understanding to all stakeholders that solving performance measurement between main targets and additional targets is carried outto meet target criteria based on logical 
Farida Kusuma Wardhani et.al. Strategy for improving the implementation of performance accountability system for government institution (SAKIP): a case study in the directorate general of human settlements (ditjen cipta karya), the ministry of public works and housing, Indonesia.

arguments and calculations. The programs based on presidential directive occurs incidentally, thus, data that shows unexpected bad or very good results are needed to be made lesson as part of the formal process (Hatry, 2002).

2. The root cause of the no outcome rule can be solved through the regulation of outcome-oriented in 2020 issued by the Directorate General of Human Settlements. The strategic plan based on these rules has been compiled.

3. For the root cause of no rule for the job descriptions in the implementation of SAKIP, the Directorate-General of Human Settlements (Cipta Karya) has advocated the preparation of a Circular of the Director General of Cipta Karya regarding the implementation of SAKIP on the legal basis of Ministerial Regulation Number 09 of 2018 concerning the Implementation of SAKIP at the Ministry of Public Works and Housing. The preparation of this Circular is carried out in 2021. It is expected that with a clear division of job descriptions, tasks, and people in charge, the implementation of SAKIP will run optimally.

4. The strategy to solve the absence of rules of data management is the preparation of SOP regarding data management. In 2020, the Program Evaluation SOP was drafted covering performance formulations, data sources, and standard performance measurements for all stakeholders in the Directorate General of Human Settlements (Cipta Karya). The preparation of various rules related to SAKIP is in line with the results of previous research conducted by Davies (1999) in his research explaining strategies in the implementation of performance management, one of which is to discuss and agree on several performance management rules.

5. The strategy for the root cause of no performance cascading is to arrange a performance tree from the organization to the individual level. The arrangement of performance cascading is needed as integration between organizational and individual performance, that each individual has a role in the organization. Poister (2010) explains the need to link performance data to a performance management system that is centered on managers and employees (integrated) so that the performance management system can be linked with rewards (Ahenkan et al., 2018).

6. The strategy for the root cause of the non-integrated information system is the integration of the existing information system into e-SAKIP as an information system that is not only related to organizational performance, but to individual performance. According to Niven (2003), the harmony between management and information technology is one of the optimal performance management factors.

7. The root causes of leader's awareness require a SAKIP training strategy for leaders to increase awareness and knowledge of the leadership and the importance of the entire performance management process on organizational performance. Strengthening the role of leadership at all levels (Bappenas, 2006) will result in good leadership (Poister, 2010). Leadership commitment and support can be carried out in terms of setting strategic direction, performance measures, monitoring and reviewing performance (Ahenkan et al., 2018).

8. The root cause related to the capacity of evaluators requires a special SAKIP training strategy or Training of Trainer (ToT) for evaluators. People who can carry out SAKIP evaluations and become trainers in SAKIP Technical Guidance are those who have obtained the certificates for a competent and reliable evaluator. Thus, the evaluation of SAKIP/ Technical Guidance can run optimally. By providing training to the staff of performance management administrators (Poister, 2010) in this 
Farida Kusuma Wardhani et.al. Strategy for improving the implementation of performance accountability system for government institution (SAKIP): a case study in the directorate general of human settlements (ditjen cipta karya), the ministry of public works and housing, Indonesia.

case the evaluators, the quality human resources (Bappenas, 2006) will be able to implement performance management evaluations, in this case, SAKIP.

\section{CONCLUSIONS}

The SAKIP of the Directorate General of Human Settlements (Cipta Karya) is implemented based on the Ministerial Regulation Number 09 of 2018 concerning the Implementation of SAKIP at the Ministry of Public Works and Housing. The SAKIP cycle of the Directorate General of Cipta Karya starts from strategic plans, performance agreements, performance measurement, performance data management, performance reporting, and performance evaluation and review at the organizational and individual levels. Based on the results of the SAKIP evaluation by the Inspectorate General, there are eight performance management problems that have been repeated until 2019 in all aspects of the implementation of SAKIP. Based on the results of the analysis, the root causes are programs based on presidential directive (budgeted), no regulations/Standard Operating Procedure (SOP), no performance cascading, non-integrated information systems, leadership awareness, and evaluator capacity. To that end, the SAKIP implementation strategy includes solving performance measurement, drafting rules/SOP related to the SAKIP, constructing the performance tree (performance cascading), integrating information systems, and SAKIP training for leaders and evaluators.

\section{Acknowledgement: None}

\section{Conflict of Interest: None}

\section{Source of Funding: None}

\section{REFERENCES}

1. Ahenkan, A., Tenakwah, Emmanuel, S., and Bawole, J. N. 2018. Performance Management Implementation Challenges in Ghana's Local Government System: Evidence from the Sefwi Wiawso Municipal
Assembly. International Journal of Productivity and Performance Management, 67(1). https://doi.org/10.1108/IJPPM-062016-0124

2. Bappenas. 2006. Manajemen yang Berorientasi Pada Peningkatan Kinerja Instansi Pemerintah (Suatu Profil). [Online]. From:

http://perpustakaan.bappenas.go.id/lontar/fil e?file=digital/100799-[_Konten_]-Konten C6723.pdf [October 10, 2020.

3. Boschken, H. L. 1992. Analyzing Performance Skewness in Public Agencies: The Case of Urban Mass Transit. Journal of Public Administration Research and Theory, 2(3), 265-288. https://doi.org/10.1093/oxfordjournals.jpart. a037131

4. Bovaird, T and Loffer, E. 2013. Public Management and Governance. London: Routledge.

5. Bungin, B. 2001. Metode Penelitian Kualitatif. Jakarta: Raja Grafindo Persada.

6. Creswell, J. W. 1998. Qualitative Inquiry and Research Design: Choosing Among Five Tradition. London: Sage Publications.

7. DARPG. 2008. Performance Management in Government. [Online]. From: https://darpg.gov.in/sites/default/files/Perfor mance_Management.pdf [October 2, 2020]

8. Davies, I. C. 1999. Evaluation and Performance Management in Government. Evaluation, $\quad 5(2), \quad 150-159$. https://doi.org/10.1177/1356389992220889 6

9. De Waal, A. A., and Coevert, V. 2007. The Effect of Performance Management on the Organizational Results of a Bank. International Journal of Productivity and Performance Management, 56(5-6), 397416. https://doi.org/10.1108/1741040071075711 4

10. de Waal, A. A., and Counet, H. 2009. Lessons Learned From Performance Management Systems Implementations. International Journal of Productivity and Performance Management, 58(4), 367-390. https://doi.org/10.1108/1741040091095102 6

11. Fryer, K., Antony, J., and Ogden, S. 2009. Performance Management in the Public Sector. International Journal of Public Sector Management, 22(6), 478-498. 
Farida Kusuma Wardhani et.al. Strategy for improving the implementation of performance accountability system for government institution (SAKIP): a case study in the directorate general of human settlements (ditjen cipta karya), the ministry of public works and housing, Indonesia.

https://doi.org/10.1108/0951355091098285 0

12. GAO, US. 2004. GPRA Has Established a Solid Foundation for Achieving Greater Results (Issue March). [Online]. https://www.gao.gov/assets/160/157519.pdf [November 1, 2020]

13. Harris, H., Brewster, C., and Sparrow, P. 2003. International Human Resource Management. London: CIPD Publishing.

14. Hatry, H. 2002. Performance Measurement: Fashions and Fallacies. Public Performance \& Management Review, 25(4), 352-358. https://doi.org/10.1080/15309576.2002.116 43671

15. Heinrich, C. J. 2002. Outcomes-based performance management in the public sector: Implications for government accountability and effectiveness. Public Administration Review, 62(6), 712-725. https://doi.org/10.1111/1540-6210.00253

16. Kementerian PAN dan RB. 2018. Permasalahan Manajemen Kinerja di Indonesia dan Upaya Kementerian PANRB Untuk Mengatasinya. [Online]. From: http://rbkunwas.menpan.go.id/artikel/artikel -rbkunwas/434-permasalahan-manajemenkinerja-di-indonesia-dan-upayakementerian-panrb-untuk-mengatasinya [August 15, 2020]

17. Lee, C. D. 2005. Rethinking the goals of your performance-management system. Employment Relations Today, 32(3), 5360. https://doi.org/10.1002/ert.20075
18. Niven, P. 2003. Balanced scorecard step by step for government and nonprofit agencies. New Jersey: Wiley.

19. Ohemeng, F. L. K. 2009. Constraints in the Implementation of Performance Management Systems in Developing Countries: The Ghanaian Case. International Journal of Cross Cultural Management, 9(1), 109-132. https://doi.org/10.1177/147059580810115

20. Patton, M. Q. 2002. Qualitative Research and Evaluation Methods. Thousand Oaks: Sage Publications.

21. Poister, T. H. 2010. The Future of Strategic Planning in The Public Sector: Linking Strategic Management and Performance. Public Administration Review, 70. https://doi.org/10.1111/j.15406210.2010.02284.x

22. Poister, T. H., and Streib, G. D. 1999. Strategic Management in The Public Sector: Concepts, Models, and Processes. Public Productivity \& Management Review, 22(3), 308-325.

How to cite this article: Wardhani FK, Salim U, Sudjatno. Strategy for improving the implementation of performance accountability system for government institution (SAKIP): a case study in the directorate general of human settlements (ditjen cipta karya), the ministry of public works and housing, Indonesia. International Journal of Research and Review. 2021; 8(4): 99-109. DOI: https://doi.org/ 10.52403/ijrr.20210415 